\title{
DIRECT FOREIGN INVESTMENT IN UNDEVELOPED COUNTRIES: SOME PRACTICAL PROBLEMS
}

\author{
Alexis Coudert* and Asher Lanst
}

The nadir of unreality in discussion of the "legal aspects" of foreign affairs is generally reached in dealing with the problem of "foreign investments." Conventionally the primary emphasis is placed upon elaborate analysis of the theories available to the advocate who participates in diplomatic discussions or litigates before a claims commission after a particular foreign investment has been confiscated or a loan defaulted. This approach is of little practical interest to either the statesman or the private investor. In the first place, it generally treats International Law as a "brooding omnipresence in the sky"-a body of revealed doctrine which somehow, somewhere will be invoked and enforced against "delinquent" nations rather than, as Sir Alfred Zimmern characterized," with pardonable exaggeration, "a decorous name for a convenience of the chancellories." ${ }^{3}$ A second and more serious objection to the traditional approach is that it conceives of the international lawyer primarily as a barrister who represents his client, whether a government or private individual, after a dispute has begun, rather than as primarily a solicitor whose most useful role is to assist his client to act in a manner which will minimize the possibility of future dispute. Like the rules of procedure applicable in a domestic tribunal, the Calvo Clause and the ambivalent principles whereby Foreign Offices determine whether they will extend diplomatic protection to claimants are of capital

* A.B., 1935. Yale University; LL.B., 1938, Columbia University. Member of the New York Bar.

† A.B., I938, Dartmouth College; M.A., I939, Columbia University; LL.B., r944, Yale University. Member of the New York Bar. Formerly lecturer in economics at Hunter College and Brooklyn College. Co-author, McDougal \& Lans, Treaties and Congressional-Executive or Presidential Agreements: Interchangeable Instruments of National Policy (1945) 54 YALE L. J. I8r, 534.

IIn this article the term "foreign corporation" is used to denominate a corporation which is owned, wholly or substantially, by organizations or persons not domiciled in the country where it operates, regardless of whether that corporation has been incorporated in that country. The terms "foreign investor" and "alien capial" are given similarly broad interpretations. The term "local government" is used to refer to the government of a country where a "foreign corporation" operates.

"Zimmern, The League of Nations and the Rule of Law (r939). Cf. Wilson, The State (i 890 ed.) 628-9; CARR, THE TWENTY YeARs' CRISIs (I94x) ch. II.

${ }^{3}$ Sir Alfred Zimmern's comment is particularly applicable to disputes occasioned by repudiation or default on international loans. In this connection it is instructive to compare the strict interpretation usually given by the British Foreign Office to international loans when Great Britain stands in a creditor position with the views expressed during the controversy over the World War I debts. See CarR, op. cit. supra note 2, at 238 . If the American Department of State and American writers have generally taken a strict position, the explanation may not unjustly be attributed to the fact that we have in recent years been primarily an international creditor. During the nineteenth century, however, when several Southern States repudiated their indebtedness, American writers were much more skilled at finding legal rationalizations suitable to the case. See Scott, The Repudiation of State Debts (I893); Madden \& Nadler, Foreign Securities (1929) 248-25I. 
importance only to litigants. The proverbial longevity of international claims makes consideration of the problem of foreign investment, from the solicitor's approach, more important in this than in almost any other field of law.

The present article is an essay in preventive jurisprudence; its concern is with the avoidance of future disputes. The focus of attention is entirely upon direct investment, i.e., acquisition of a substantial ownership interest in property or in an enterprise in a foreign country. ${ }^{4}$ Even in this restricted formulation it is necessary to deal with matters sometimes catalogued by academicians as extraneous to the field of International Law. But like his domestic colleague's, the international lawyer's law cannot safely be confined to treaties, decisions and treatises. He is remiss in his function as counsellor unless he is prepared to deal with a wide variety of "non-legal" factors in collaboration with specialists in economic, political and psychological problems. ${ }^{\overline{5}}$ The necessity for this approach has, of course, been realized by practitioners, both governmental and private, for many years. But the discussion of International Law, unaffected by the trend of recent legal writing in other fields, has persisted in its preoccupation with high-level abstractions. It is time that attempts were made to bridge the gap between the realities of practice and the arid legalisms of the literature.

\section{Characteristics and Advantages of Direct Investment}

As Professor Condliffe has stated, "even before the breakdown of exchange stability brought the collapse of the international capital market after I93I . . . international lending was tending to dry up," except for loans to governments, and to become less important than direct investment. ${ }^{6}$ The flow of American loans to Europe during the period I925-I929 was but a transient exception to the general trend and, in any case, was over-shadowed in importance by the establishment of branch factories and by the network of productive enterprise built up by American (and other foreign) capital. ${ }^{\top}$ The growing tendency of large corporations to accumulate surpluses exceeding capital replacement $\operatorname{costs}^{8}$ and the greater safety possessed by the international creditor when the actual investment remains under his own management were probably the original reasons for this shift in the form of investment. These motives were reinforced by the Neo-Mercantilistic legislation concurrently enacted in most countries. American industrialists then sought to avoid tariff $387-9$.

*For a catalogue of types of foreign investment, see Young, The Internationsl Economy (I942)

${ }^{\circ}$ Cf. Lasswell \& McDougal, Legal Education and Public Policy; Professional Training in the Public Interest (1943) 52 YaLe L. J. 566; Moore \& Sussman, The Lawyer's Law (1932) 4I YALE L. J. 566.

'Condlffe, The Reconstruction of World Trade (1940) 342; see also U. S. Dep't op Comm., Tre United States in the World Economy (r943) 102 (Economic Series, No. 23). Frequently, American corporations "capitalized" direct investments after their initiation by selling to the public additional of their own securities or the securities of the foreign corporation which operated the investment. Ilid.

'Dep's of Coms., supra note 6, at Iox-5; Southard, AMERICAN INDUSTry in Europe (I931); U. S. Dep't of Comm., Trade Information Bulletin No. 73I (r931); Condliffe, op. cit. supra note 6, at 329-332.

${ }^{8}$ See 9 Hearings before the Temporary National Economic Committee, 76th Cong., Ist Sess. (t940) 3576-3702; ConDLIFFe, op. cit. supra note 6, at 342 . 
barriers by construction of branch plants and assembly lines in Protectionist countries. The imposition of exchange controls in the I930's, while a long-run menace, increased the volume of direct investment in some countries by impelling reinvestment of profits. ${ }^{9}$

It may be assumed that during the next few years private capital migration will predominantly take the form of direct investment. Long-term security flotations are currently held in abeyance by the uncertainty as to the rates at which many foreign currencies will eventually be pegged ${ }^{10}$ and by the reluctance of private bankers or prospective borrowers to enter into loan agreements until the interest structure and general policies of the International Bank for Reconstruction and Development are established. ${ }^{11}$

On the whole, the safety record of direct American investment has been superior to that of portfolio investment. The available evidence tends to indicate that direct investments have produced a larger average return over the course of years than have security issues. ${ }^{12}$ While generalized statements have the most limited validity, it would appear that limitations on profit repatriation and restrictive legislation have been less of a burden on creditors than the wave of defaults. Moreover, apart from the expropriation of oil properties in Mexico and Bolivia, the exercise by foreign governments of their inalienable right of eminent domain has been accompanied

${ }^{\circ}$ Condliffe, op. cit. supra note 6, at 343. This practice was perforce adopted by the General Motors Corporation in Germany after I933. While by no means satisfactory to the corporate management, this resulted in the conversion of the Opel plant at Russelsheim into the world's most completely integrated automotive unit. General Motors Overseas (Nov. 1945) Fortune Magazine 125, 262. It is also notable that a substantial volume of private direct investment was made by Americans during the 1930's, involving transfer of fresh capital from the United States. See Dep'T of CoMM., op. cit. supra note 6, at ro3.

${ }^{10} \mathrm{Sec}$ the provisions for initial and subsequent changes in par values included in the Articles of Agreement of the International Monetary Fund (I945) Art. XX, Secs. 4(b) and (f); Art. IV, Sec. 5; U. S. Dep't of State, Treattes and Other International Acts, Series I501 (1946) 4-5, 29-30.

${ }^{11}$ The only large private international loan now outstanding is a 10 million dollar credit to Norges Bank, Central Bank of Oslo, declared effective July 15, 1946. (New York Herald Tribune, June 9, 1946, sec. 4, p. I.) The roo million dollar bank credit to the Netherlands, originally arranged by private firms, was replaced by a Federal Reserve Bank loan and supplemented by an Export-Import Bank loan. The recent loan to Denmark was a joint venture by the Export-Import Bank and private institutions; the terms, however, were controlled by the Federal agency. (Business WeEx, May 18, 1946, p. r r4.)

12 "The relative ability of direct and portfolio-investment income to adjust to changing economic conditions is evidenced by the comparative declines in these items -82 per cent and 24 per cent, respectively-from 1929 to 1932 . The advantage to the debtor country, in times of depression, of having obligations the service on which is adjustable, is evident. Although income from direct investments has often been blocked and substantial losses to investors have occurred through reorganizations of American companies operating abroad, direct investments weathered the depression with considerably lighter losses to investors, both of principal and interest, than did foreign bonds. Moreover, direct-investment holdings have not given rise to international controversy and ill will to an extent comparable to that which accompanied defaults on foreign dollar bonds." Dep'T of Comm., op. cit. supra note 6, at 83 .

Between December, 1929, and December, 1939, United States long-term foreign investments declined from 7.8 billion dollars to 7 billion dollars; during the same period, long-term portfolio holdings, valued at par, declined from 7 billion dollars to 3.8 billion dollars. (Ibid. at 84 .) During the period from December, 1939, to December, 1944, long-term investments increased by 300 million dollars; during the same period, portfolio holdings, valued at market, had declined to I.7 billion. See National City Bank of New York, Newsletter for April, 1945, p. 43. 
by eventual enactment of provisions for compensation of the ousted investors, which accorded admittedly fair treatment to the former owners. ${ }^{13}$

From a long-run economic standpoint, direct investment has demonstrable advantages for creditor and debtor nations as well as private investors and should be encouraged by national policy-makers. In the first place, international financial operations characteristically involve debt securities. Particularly in economically immature countries whose international role is predominantly that of selling agricultural or mineral products on sharply fluctuating world markets, the borrowing nation will almost certainly be unable to meet the fixed charges for extended periods, except by drastic curtailment of its imports and imposition of exchange controls. In addition, where the debt issue is guaranteed by the national government or bank-as is the practice of the Export-Import Bank and as is required by the charter of the International Bank ${ }^{14}$-the failure of the enterprise for which its proceeds were utilized will saddle the rest of the debtor's economy with the problem of producing additional foreign exchange. Conversely, the direct investor has recourse only to the resources of a single enterprise, whose bankruptcy is a normal and calculated risk, not the occasion for an international dispute.

Secondly, direct investment is in the aggregate less expensive since there are no commission and brokerage charges to meet. ${ }^{15}$

In the third place, there is a greater likelihood that direct investment will strengthen the economic structure of the capital-importing country by permanently increasing its productive capacity. A corporation which risks its own funds in an overseas investment has a constant and impelling motive to make certain that the funds are used productively. Its initial investigation is likely to be more thorough than that of the investment banker whose personal stake survives only until an issue is completely distributed to the public. Once the investment is made, the direct investor can exercise more effective supervision of operations through its own managerial and technical staff than even an International Bank. ${ }^{16}$

In the fourth place, direct investment creates the maximum opportunity for cooperation between local and foreign interests. In particular it facilitates instruction of local personnel in modern techniques on the production line as well as in technical and managerial positions. Moreover, it affords the simplest and most satis-

\footnotetext{
${ }^{23}$ It is as yet too early to tell whether the expropriations by the present Argentine régime will be adequately indemnified. See Holmes, Argentina (Feb. I, 1946) Forfign Policr Reports.

1s Articles of Agreement of the International Bank for Reconstruction and Development (1945), Art. III, Sec. 4(i); Dep't of State, Treaties and Other International Acts, Series 1502 (1946) 5.

${ }_{15}$ During the $1920^{\prime} \mathrm{s}$, bond discounts and premiums on some forcign issues floated in the United States aggregated 13 per cent. Young, The InTERNAtiondL Economy (1942) 390, note 6. More commonly, the "spread" between the purchase price and the public offering price ran from 5 per cent to 7 per cent. Madden \& NADler, Foreign Securimes (r929) 75. The organization of the International Bank makes recurrence of such margins highly improbable, except for marginal loans, since borrowers will be able to use the direct lending capacity of the bank when private charges are cxorbitant.

Where the direct investment is financed by a security flotation by the foreign investor, its ordinary comparative cheapness is pro tanto reduced.

${ }^{20}$ For a fuller discussion of the advantages of direct as contrasted with portfolio investment, see Dep'T of CoMs., op. cit. supra note 6, at 103-5.
} 
factory method for joint utilization of indigenous and imported funds. This is particularly true in economically immature countries where the largest available capital reserves are possessed by the government and by landowners without industrial experience.

The governments of undeveloped countries have recently shown a uniform recognition of the preferability of direct investment. Thus, in the past year the Chinese Communist and Kuomintang régimes and the provisional government of Indonesia have invited American business to participate in the industrialization of the territories under their control and have, in some cases, modified restrictive enactments. ${ }^{17}$ Except in the Argentine Republic, the nationalistic legislation adopted in many Latin-American countries in the last decade has apparently been intended not to bar foreign capital but to prevent foreign capital from monopolizing key industries and to redress past exploitative practices. This legislation and general governmental policy in Latin America are already beginning to result in the formation of mixed corporations, as joint ventures by local and foreign interests. This desirable tendency will be discussed in detail infra.

\section{Facing the Charges against Direct Investament}

However, direct investment entails certain special risks. A large-scale direct investment is inevitably less liquid than an equally large security issue, ${ }^{18}$ and local legislation recently enacted in some countries precludes sale to other foreign interests except with governmental consent. ${ }^{19}$ Moreover, financially embarrassed governments are likely to prohibit repatriation of principal and profits before they default on international loans. Direct investment in under-developed areas is also a more obvious and therefore more dangerous flaunting of foreign control in the faces of peoples turned hypernationalistic by past imperialistic policies. It is therefore especially subject to deterioration through enactment of discriminatory taxation or other legislation after its devotion to local use.

Generally speaking, defaults on international loans are occasioned at least initially by genuine inability on the part of the debtor to secure the needed foreign exchange except by drastic deflation of its economy. ${ }^{20}$ But direct or indirect expropriation has sometimes been the result of deliberate national policy which dis-

${ }^{17}$ See, e.g., New York Sun, May 9, 1946, p. 3; Rosinger, China As a Postwar Market (Jan. I, 1945), Foreign Policy RePorts. In connection with the invitation extended by the Chinese Communist régime, it is interesting to note that the Soviet Russian Government has since its inception maintained a punctilious record in meeting its own international financial obligations. See Gerschenkorn, Economic ReraTIONS WITH THE USSR (1945) 68.

${ }^{18}$ The situation has been somewhat alleviated by the large accumulations of foreign exchange, and particularly blocked sterling balances, built up in certain Latin-American countries during the war, which could be used to purchase foreign direct investments. See Holmes, supra note 13.

${ }^{10}$ See infra note 39.

20 The Foreign Bondholders Protective Council has cited the fact that various Latin-American countries which defaulted on dollar bonds subsequently maintained favorable balances of trade with the United States, as evidence of bad faith. The argument is by no means conclusive. See OLson AND HickMan, Pan Amicrican Economics (r943) 189-190; Feuerletn \& Hanin, Dollars in Latin America (1941) 26-36. 
regards the economic benefits of direct investment in the form of more rapid development of natural resources or utilities than would otherwise be possible.

Realistic appraisal of methods for avoiding the "crisis" situation where a government may be driven to expropriation ${ }^{21}$ and of forestalling the growth of a hostile legislative atmosphere must begin by examination of the more common charges levelled against foreign enterprise:

I. The charge that foreign corporations have frequently made excess profits on their investments.

2. The charge that alien capital has helped perpetuate "colonial dependence" by its preoccupation with the exploitation of depletable resources and its failure to develop more balanced economies. Specifically, it is alleged that foreign corporations have failed to reinvest any substantial proportion of their profits in other local enterprises. It is also alleged that foreign corporations have frequently violated labor legislation.

3. The charge that foreign corporations have evinced a lack of respect for the local government and population by declining to domesticate themselves wholeheartedly in the countries in which their properties are located.

4. The charge that foreign corporations have interfered in local politics.

It is of course impossible to determine the general truth or falsity of these charges. However, foreign corporations can scarcely afford to take a position of blind and continuous opposition to ardently supported programs of reform. Business statesmanship requires re-examination of operating practices; cooperation on the part of business enterprise in drafting regulatory legislation should be calculated only to produce fairer and more effective techniques of control.

Excess Profits. The fact that direct investments in backward regions have frequently been more profitable than similar investments in better developed countries is entirely understandable. Absent monopolistic control, the rate of profit in a given line of business generally tends to decline with the development of the industry. This tendency is, in fact, one of the primary reasons why capital is attracted to under-developed areas. But the higher rate of profit in under-developed countries is a function of the marginal efficiency of capital and not the national origin of the entrepreneur; well-managed local enterprises are equally successful. ${ }^{22}$

In situations where a foreign subsidiary sells its output principally to its parent corporation, it has sometimes been possible to conceal the true rate of return by reducing the sales price below world market levels. This may have the effect of reducing unfairly royalty payments collected by the local government under concession contracts and may also defraud minority (including indigenous) shareholders in the subsidiary by artificially lowering its income. Such essays in high

\footnotetext{
${ }^{21}$ An American government expert concluded that the expropriation of foreign oil concessions in 1938 was not the end of Mexican Government policy, but the unfortunate result of intransigence on the part of those companies and the local oil workers' union. Person, Mrxicas Orl (1942) 47-55.

22 Thus banks in certain Latin-American countries regularly chargc Io per cent or 15 p:r cent per annum on industrial loans.
} 
finance are admirably calculated, however, to discredit permanently all foreign enterprise.

In the past, many governments have sought to participate in the proceeds of the exploitation of their natural resources and thus indirectly to limit profits by including provisions for large percentage royalty payments in concession contracts. The necessity for negotiating a new contract for each concessionaire sometimes prompted not unjustified charges of discrimination against established investors. In certain situations, the piecemeal approach also fostered attempts by particular prospective investors to secure special favors from the contract-signing officials of the local government; disputes with reform administrations in Latin America have often centered about their attempts to rescind the largess of earlier and less independent governments.

The evils of favoritism can best be obviated by the enactment of general concession legislation in each country. A prototype of such legislation is the Venezuelan Hydrocarbon Law of 1943, governing conditions under which petroleum and natural gas concessions are to be granted and also providing for conversion under the terms of the new statute of concessions granted under prior legislation. Analogous uniform petroleum concession statutes are now under consideration in Guatemala, Peru, Bolivia and other countries. ${ }^{23}$

However, the present tendency to provide for substantial royalty payments to the local government, whether pursuant to uniform legislation or to the terms of individual contracts, is tainted by the usual drawback of proportionate taxation in that it levies an equal charge upon the highly profitable, the mildly profitable and even the unsuccessful venture. During the past year, the Venezuelan Revolutionary Junta has experimented with a new technique by enactment of a one-year additional corporate tax, applicable on a sliding scale basis to all profits in excess of 300,000 Bolivars, and Uruguay has enacted excess profits taxes based on an invested capital formula. ${ }^{24}$

Of course, an "excess profits tax" which takes effect when profits reach a fixed absolute level, rather than when they exceed a specified rate of return upon investment, places an unjustifiable and uneconomic burden upon bigness as such. ${ }^{25}$ But whatever the general merits of excess profits taxation, there is a clear case in favor of the imposition of such levies upon foreign capital in undeveloped countries. ${ }^{\mathbf{2 6}}$ This is demonstrated by comparing the effect upon the American economy of large profits earned by domestic corporations in the United States with the effect of equiv-

${ }^{23}$ E.g., Venezuelan Hydrocarbon Law, Gaceta Oficial Numero Extraordinario 31, of March 13, x943. The Government of the Dominican Republic has enacted a series of separate concession laws governing exploitation of various mineral resources. Sce REPORT, infra, note 24, at I21.

34 See Report of the Committee on Latin-American Law, in AM. BAR Ass's, Proceedings of THE Section of International, and Comparative Law (1945) il 8.

${ }^{25}$ Cf. Arnold, The Bottlenecks of Business (1940) 3-4, 66, 122.

${ }^{20}$ The suggestion is, of course, subject to attack as involving discriminatory levies against foreign corporations. We believe, however, that it would be economically desirable for the reasons stated in the text. 
alent profits earned by a foreign corporation upon the economy of the local nation. Generally, an American corporation will reinvest a substantial portion of its profits in productive enterprise in the United States by expanding its operations or otherwise. If an unreasonable amount of profit is retained, the corporation is subject to the surplus tax provisions of Section roz of the Internal Revenue Code. On the other hand, the same corporation when operating in a backward area will probably attempt to repatriate the greater part of its local profits. Particularly in the case of petroleum or mining corporations, this subjects the foreign investor to the not unjustified reproach that it is rapidly depleting the limited natural resources of the country without creating a permanently valuable industrial establishment. ${ }^{27}$

It would seem wise for American corporations to suggest that the excess profits problem be dealt with either (a) by supplementation of low flat rate royalty payment terms in concession contracts by sliding scale payments proportioned to the profitability of the enterprise, or (b) by enactment of taxation keyed to the rate of return on invested capital. If foreign investors cooperate in the institution of such controls, they may reasonably expect to gain countervailing benefits in the form of loss carrybacks and carryforwards and in the avoidance of taxation which is an undiscriminating levy on mere bigness. Both foreign investors and the local economies would benefit if the suggested legislation contained exemptions for profits reinvested in the country of origin.

A particularly difficult problem of profit control exists in the case of public utility companies. In contrast to the United States' method of regulation by public utility commission through application of fair rate of return formulae, the basis of regulation in Latin America has generally been the term concession contract containing "fixed rights and obligations." 28 This technique of control has certain serious defects. As the contract is necessarily made for an extended period, the rates fixed therein will ordinarily tend to become excessive, as an increase in the volume of sales reduces the unit overhead costs. (On the other hand, if the demand for service increases slowly and if the local wage and price level is inflated, the fixed rates may fail to provide a fair rate of return to the utility company.) $)^{20}$

In the second place, even if a term contract contains no express reversionary clause, prudent accounting may require accumulation of a substantial reserve for amortization of the entire fixed capital account over the life of the contract, in com-

\footnotetext{
${ }^{27}$ In mature economic countries, such as England and Belgium, which have long since exhausted certain of the mineral deposits upon which their industrialization was originally predicated, the profits and technical skills accumulated during the early period served to create industrial systems with permanent productive utility. The governments of under-developed areas can scarcely be blamed for atternpting to secure the same benefits for their own people.

${ }^{28}$ In preparing this section, the present authors have drawn freely on Ford, Recent Trends in Regulation of Public Utilities in Latin America and Their Effect on the Ability of Public Urility Contpanies to Meet Demands for Service (x94I) I Proceedings of the First Conference of Inter-American Bar Assoctution 347 et seq. They do not, however, subscribe to all of Ford's views.

${ }^{20}$ The remarks in the text should not be construed as an indirect defense of the "replacement cost new" formula of rate control.
} 
parison to the United States' practice which requires only the accrual of a reserve for retirement of actual obsolete equipment. ${ }^{30}$

The solution for these difficulties would seem to lie in the introduction of a method of control which combines provision of indeterminate lives for concession conracts with regulation of rates and other practices by utility commissions. ${ }^{31}$ This would permit local industrial and domestic consumers to receive the benefit of reductions in cost when the volume of consumption increases and simultaneously protect the utilities companies against the contingency of inflation. Similarly, the suggested legislation would remove the necessity or justification for management to make excessive amortization charges.

It would seem to be wise for foreign owned utility companies to take the initiative in recommending the adoption of a modernized technique of rate control. In certain instances, Latin-American and other governments in undeveloped areas have used the threat of competition as a means of forcing rates downward. But the disadvantages of excess competition in public utility industries have long been apparent. Local consumers would benefit if control by threat were replaced by control by commission; concurrently, the existing utility concerns would be freed of one of their principal bogeys. ${ }^{32}$

Quasi-Colonial Investment Policies. From the foreign corporation's point of view there is no business reason why profits should be reinvested locally in industries in which the investor has no experience; and investors would be acting contrary to their own short-run interests if they eschewed the obvious profits available in certain extractive industries. But this does not lead to the conclusion that foreign capital has most intelligently protected its own long-run interests by a policy of concentrating investments.

For, except in time of war, the terms of international trade have been shifting against the producers of raw materials continuously for three-quarters of a century. However efficiently managed, an isolated investment in the producers' or semidurable consumers' good industries in a backward country might well prove unsuccessful. But collaboration by private and governmental interests in the formulation of a broad plan for development of industry and diversification of agriculture is likely to create opportunity for private capital to earn higher long-run average returns than by continued concentration of investment in the extractive fields for export markets.

An immediate source of conflict is the reluctance of foreign investors to erect plants for processing in backward countries any substantial proportion of locally pro-

${ }^{30}$ Ford, op. cit. stipra note 28 , at 349-50.

s1 For a definition of an indeterminate concession, see Sections 2r, 22 and 23 of The Uniform Public Utilities Act in Proceedings of the National Conference of Commissioners on Unifordi State Latrs for 1928 .

${ }^{32}$ The constitutions of many Latin-American countries prohibit exclusive concessions. This is desirable in the ordinary situation, where the foreign corporation has no right to expect anything better than what might be described as "most favored investor" status. However, it is reasonable to assume that most governments would be willing to make exceptions in favor of designated classes of public utilities, after they had enacted suitable control legislation. 
duced raw materials. The real reasons for this reluctance are probably the desire to utilize fully the productive capacity of processing plants previously constructed in more important market areas and the feeling that unstable political conditions make it judicious to minimize the extent of capital investment. This latter argument probably explains why certain petroleum concessionaries have preferred to refine crude oil produced in Venezuela in the Dutch colony of Curacao.

From the standpoint of an economically mature nation, it is easy to stigmatize as "mercantilistic" legislation or concession policies adopted in more backward countries which exert pressure to hasten industrialization. But as both Sumner Welles and Alvin Hansen have pointed out, the general American policy of encouraging relaxation of trade barriers does not necessitate opposition to reasonable protectionist measures in unindustrialized countries. At present such policies are frequently covert. Thus although there are no relevant provisions in the Hydrocarbon Law, the Venezuelan Government now sometimes conditions grant of a substantial petroleum developmental concession up an undertaking by the concessionaire to build a refinery of specified capacity in the Republic.

It is to be hoped that such policies are included in the agenda of the forthcoming International Trade Conference and that haphazard and surreptitious local polices are superseded through international cooperation.

During World War II the United Fruit Company initiated elaborate plans designed to diversify the agricultural production of Central American countries. ${ }^{33}$ However, such projects extend the area of foreign or monopolistic control of a country's economy. It is understandable that the local government and population should disregard the economic advantages of such plans because of their concern over the loss of "effective national independence." Partnership between local and foreign capital in such developmental schemes appears to be the only satisfactory long-run solution.

Domestication of Foreign Enterprises. Since foreign capital usually does business through the medium of locally incorporated subsidiaries, the desire of most governments for domestication of foreign enterprises has generally been formally met. $^{34}$ Greater conflict has been created by the not unreasonable legislation enacted in many Latin-American countries requiring that a designated minimum of the supervisory employees of foreign-owned enterprises be local citizens. ${ }^{35}$ Provided the problem is approached with reasonable goodwill, this kind of legislation should ordinarily create little difficulty for foreign corporations and should work out to their long-run advantage by creating a class of skilled employees that can play

${ }^{33}$ Polzan, The United Fruit Company and Mtddle America (1944), including introduction by - Henry Wallace.

${ }^{34}$ Local incorporation does not preclude the foreign stockholder from having diplomatic intervention made in its behalf by its government. See cases in 3 Moore, Digest of Internatronal Law (1905) 647, 651; Borchard, The Diplomatic Protection of Citizens Amroad (1915) 622-23; Hackworth, Digest of International LaW (1941) 837-844.

${ }^{35}$ See Olson \& Hickman, Pan American Economics (1943) 194-5; Report, op. cit. stipra note 24, at Ir9, 122; see also note 39 , infra. 
an important role in bridging psychological gaps between foreign investor and local country.

Still less susceptible to formal discussion is the problem created by the reputed failure of American business representatives to participate in the community life. Both in the Far East and in Latin America, the proverbial insularity of the British businessman overseas has been at least equalled by that of his American competitor. Consonant with the traditional practices of local branch managers in the United States, it is suggested that the Rotarian spirit, membership in the local country club, and intermarriage are as useful in Peru, S. A., as in Peru, Ind.

"Milk for the Hottentots." Under this catchy phrase, Mr. Henry Wallace was censured not long ago by various American business interests for suggesting that the granting of American developmental loans should be conditioned upon the establishment of improved working conditions in the proposed projects. Upon a larger scale the attempts of "backward" governments, particularly in Latin America, to enforce progressive labor legislation have sometimes been a source of resentment on the part of foreign capital.

The "paradox" of advanced social legislation in industrially backward countries is partly explicable in terms of the fact that local industry primarily caters to domestic markets and, when protected by tariff barriers, need not worry about the cost of production in world markets. ${ }^{36}$

In point of fact, the provisions of so-called "advanced" labor codes, such as Article I23 of the 19I7 Mexican Constitution, do not exceed the recommendations of careful students of industrial relations, as embodied, for example, in the Codes of the International Labor Organization. ${ }^{37}$ Since the pattern of social legislation in the United States has finally reached a level of development attained decades before in other mature industrial nations, American employers may now find it not unreasonable to accord their foreign employees the same working conditions as their domestic employees.

The criticism that institution of a higher wage scale for employees of modern plants in backward countries, predicated upon productivity, will create a disproportion in the wage scales of these nations can scarcely be treated seriously. Similar, although less marked, disproportions already exist within the wage scales of the more advanced industrial nations and are an ineradicable feature of any untotalitarian economy.

Those foreign corporations which have maintained better working conditions and paid higher wages than required by statute or custom have often found that

${ }^{36}$ Olson \& HrckMan, op. cit. supra note 35 , at 193 .

${ }^{37}$ For a succinct summary of labor and social security legislation in the various Latin-American Republics, see Soule, Efron \& Ness, LATin AMerics in the Future World (1945) 13. The authors point out that the labor codes of many countries are modelled on the I.L.O. Codes. See also, Some Aspects of Recent Social Legislation in Latin America (1942) 76 Bull. Pan American Union 83. The suggestion that social legislation in certain countries is directed against foreign capital [sec, e.g., Orson \& Hickian, Pan American Economics (1943) ig2; Royal Institute of International Affairs, The Republics of South Americs (1937) 200, 207] lacks factual substantiation. 
the increased productivity of their employees more than defray the additional costs. Moreover, by compensating their employees on the basis of their productivity in lieu of paying wage rates at existing low levels, foreign (and other) owners of modern industrial plants would be helping to enlarge the domestic markets in backward countries and therefore to create conditions in which better balanced economies could emerge, with larger over-all opportunities for investment. ${ }^{38}$

\section{Partnership between Local and Foreign Capital}

Prompt adjustment of managerial policies in light of charges such as those discussed above would do much to remove tangible and rational grievances. However, the fundamental problem which now confronts foreign enterprise is that of adapting itself to the new economic nationalism of Latin America and the Near and Far Eastern countries, exemplified by a wave of restrictive legislation and, more important, by the general determination not to permit alien capital to maintain a dominant position in local life. ${ }^{39}$

To some extent this tendency is the understandable reaction to past imperialistic policies. The mere elimination or denaturing of Dollar and Sterling Diplomacy can scarcely be expected to erase eo instante resentments engendered by a century of political interference. ${ }^{40}$ Moreover, while Foreign Offices, in the ordinary situation, now confine their activities to the proffer of "Good Offices," of foreign corporations persist in the old ways. ${ }^{42}$

Gauged by a strictly pecuniary standard, there can be no doubt that foreign capital has developed the resources of backward areas more rapidly than would have been possible by exclusive use of local funds and enterprise. But the Peruvian or the Burmese may be pardoned for taking a less dispassionate view and for resenting ownership of the majority of the important industries in his homeland by

\footnotetext{
${ }^{38}$ Probably labor exploitation is most marked on plantations and other large-scale agricultural cstablishments, whether owned by local or by foreign interests.

${ }^{39}$ For descriptions of some of the recently adopted legislation see Holmes, Can Latin America Build a New Economy (April I, 1945) Foreign Policy Reports 24; Holmes, Brazil: Rising Power in the Americans (Oct. x5, I945) Foreign Policy Reports 215-6; Olson \& Hickman, Pan American Economics (1943) igi-6; Ejghth Report of the House Special Committee on Postwar Economic PolICY and Planning, 79th Cong., 2d Sess. (H. R. Rep. No. 1527, 1946) part 2; Wythe, Industry in LAtin AMerica (1945) I-40.

${ }^{10}$ Resentment at past "deals" between large foreign corporations and corrupt past administrations are still a vital factor in Mexico and Venezuela. See Soule, EFron and NEss, op. cit. supra notc 37, at 8r; Person, Mexican Oil (r942).

There is an interesting analogy here to the persistence of "anti-Yankee" feeling in South America, even after 13 years of the Good Neighbor Policy. For a broadside defense of the record of American investors in Latin America, see Bemis, The Latin-American Policy of the United States (1944).

${ }^{11}$ The United States played an important mediatory role in the disputes between the Mexican Government and private oil interests in 1927-28 and 1938-43 and again in the controversy over the conduct of foreign concessions which led to the enactment of the Venezuelan Hydrocarbon (Petroleum) Law in 1943. It is believed that President Roosevelt himself intervened in the latter dispute.

"See Dep't of State Press Release No. 929, issued December 11, 1945, after receipt from the Equadorian Government of information that a road-building contract with an American company had been cancelled on the ground that the company in question "was involved in a plot to overthrow that government." See also Dep't of State Press Release No. 850, issued November 13, 1945, p. 4 .
} 
foreigners, ${ }^{43}$ whether or not the absentee landlords pursue enlightened policies. Moreover, there is a kernel of hard economic truth embedded in the New Nationalism. "There is much to be said for the view that those [undeveloped] countries have had an excess of foreign investment" ${ }^{\prime 4}$ devoted principally to extractive industries, which have done relatively little to improve their general economic status. ${ }^{45}$

It is probable that under the new dispensation there will be a decline in the relative importance of foreign investment in undeveloped areas. This by no means necessitates a diminution in the total of alien capital which can be productively and safely invested. ${ }^{46}$ On the contrary, assuming two general conditions are observed, there is every reason to believe the next decades will bring an unprecedented expansion in direct capital migration.

In the first place, the past haphazard pattern of direct (and financial) investment will have to be subordinated to general developmental programs. Such programs were outlined prior to and during the war, in a half-score of countries, to facilitate diversification of agriculture, growth and geographical spread of industry, and improvement of transportation facilities. ${ }^{47}$ To avoid a new wave of defaults, the major portion of the necessary investment will have to be made with local funds. ${ }^{48}$ But such programs are inevitably in some measure dependent upon for-

${ }^{43}$ For information as to the importance of foreign investment in certain backward countries, see Royal Institute of International Affairs, The Problem of International Investment (i937) 223; Andrews, Burma-An Experiment in Self-Government (Dec. 15, 1945) Foreign Policy Reports; Bain \& Read, Ores and Industry in South America (1934) 346; Rearer, Foreign Investments in China (1933).

"Holmes, Can Latin America Build a New Economy (April 1, 1945) Foreign Policy Reports 24.

${ }^{25}$ In countries such as Peru, Venezuela, or Indonesia, foreign capital has been devoted principally to industries producing goods for export markets. But the economies of these countries remain basically backward; the overwhelming majority of the population is engaged in subsistence farming. The foreign enterprises do, however, contribute tax payments and foreign exchange. See Soule, EFron \& Ness, op. cit. supra note 37, ch. 8; Royal Institute of International Affairs, The Republics of South AmerICA (I937).

For figures as to the distribution of American direct investment in Latin America by industries, see U. S. Dep't of Comm., American Direct Investament in Foreign Countries (1940) 23.

${ }^{20} \mathrm{An}$ instructive analogy is provided by the effects of industrialization in previously retarded areas on the importation of manufactured goods. A century of experience demonstrates that the greatest volume of trade takes place between the most heavily industrialized areas. Germany became a more valuable customer of Great Britain after 1870 , and Japan of the United States after 1890 , because of their own internal development. See League of Nations, The Network of World Trade (1942); British Information Services, Great Britain (1946) ch. 8; Stalex, World Economic Development (1944) ch. 8.

iT Sec Fong, The Post War Industrialization of China (1942); Lorwin, National Planning in Selected Counrries (r942) Pt. IV; Elisworth, Chile (I943). For discussion of the possible effects of industrialization of backward areas on more mature countries, see STALEY, op. cit. stipra note 46 , in chs. $5,8,10$.

"There are two basic reasons for this. Much of the investment necessary for "economic modernization" takes the form of highway and railroad construction, erection of power plants, building of an educational system and other projects which neither increase export capacity nor decrease import needs, in proportion to their costs. Secondly, many of the necessary projects have heavy capital costs with relation to their income-producing capacity. See Buchanan, International Investment and Domestic Welfare (1945) Pt. I; Knight, Morocco as a French Economic Venture (1937). To the extent that these projects are financed by forcign funds, it would be economically sensible to have them be interestfree and subject to repayment over very extended periods of time. [Of course, there is no reason to assume 
eign borrowing, and the possibilities for accumulating exchange with which to meet interest and amortization charges can be adversely affected by uncontrolled direct private investment. Such steps as the erection by foreign interests of a factory selling to the domestic market create an eventual demand for foreign exchange to permit repatriation of part of the profits. Accordingly, a country which is undergoing planned industrialization must regulate the utilization of foreign funds. ${ }^{40}$ Almost every government already possesses reasonably effective controls over international borrowing; in undeveloped countries, it is equally important to control the areas where direct foreign investment is made. The initial step in this direction has been taken in Brazil and China, where the establishment of a foreign-owned enterprise requires consent of the central economic authorities. Where foreign funds are to be employed in a developmental program, an International Agency should participate in the formulation of the plan. It may be assumed that this will be the case when the International Bank for Reconstruction and Development is the source of the funds. Appropriate means should be found to allow the Bank to participate in the devisal of plans, even where the foreign financing is wholly carried out by private institutions. Otherwise the present hopes for creation of a "brave, new" International financial system will be undercut gradually because of the absence of central coordination.

In the second place, foreign enterprise can maintain its position only by taking indigenous business groups or local governments into partnership. It is too late to seek refuge in mere reform programs. In fact, industrialization proceeded so rapidly in many countries during the war that, if foreign capital persists in proceeding on its own, local governments may well conclude that their only essential need is the importation of foreign managerial and technical experts.

New forms of business organization will have to be developed to meet these new conditions. In the past, the bi-national corporation has been characterized by the retention of managerial and financial control by the foreign stockholders. Recent legislation in Mexico, Brazil and other countries requires that majority stock ownership be retained by local nationals. ${ }^{50}$ It would be wise for foreign investors in other countries to accept minority equity positions and to reduce the extent of their representation on directorates and in active control of local operations without

that the disastrous pattern of international lending during the 1920's and 1930's will be exactly paralleled, as too many of the foreign loans during this period were made to governments for public works and other uses not productive of forcign exchange. Sce 2 Schumperer, Business Cycles (1939) 714722; SAlter, Recovery: The Second EFfort (1932), chapter on "Good Lending and Bad."]

so Subject to appropriate international controls, a country in this position will also have to control the utilization of foreign exchange by its own citizens, to prevent diversion to the acquisition of luxuries. As Professor Fetter has. remarked, "In more than one Latin-American country that is reputedly 'short of capital' the sums that have been spent in Paris in the last half-century by wealthy natives would have endowed the country with a modern transportation system and a well equipped industrial plant. The same situation is found in some of the countries of the Orient." Fetter, The Need for Postwar Foreign Lending (1943) 33 American Economic Review (Supp.) 342, 343. Such controls should, of course, be exercised in collaboration with the International Monetary Fund.

${ }^{20}$ See sources cited supra note 39. 
waiting for the adoption of analogous statutes. Moreover, provision should be made for amortization of part of the foreign investment so that ownership becomes increasingly domestic.

The progressive managements of certain companies have already taken the first steps in this direction. Thus a substantial proportion of the stock in the Brazilian, Chilean, and Costa Rican subsidiaries of American \& Foreign Power Co., Inc., is now held by nationals of those countries; local citizens comprise a majority of the Board of the latter two corporations. In the last year, a number of electrical, plastic, and rubber manufacturing corporations have been organized in Mexico and other countries as a result of joint investment by United States and local groups.

Many governments-including those controlled by the conservative parties in Iran and Turkey ${ }^{51}$-have announced their intention of controlling or actively participating in the operation of key industries and the development of important natural resources. ${ }^{52}$ In economically retarded countries, this is the only way to prevent domination of the state by private monopoly; moreover, the government may be the only local group able and willing to invest large amounts of equity capital.

This policy need not function as a closed door to private investment. Thus, despite their general nationalistic policies, both the Venezuelan and the Colombian Governments have evidenced their willingness to extend substantial credits to foreign corporations willing to organize and operate plants under joint control. The particular aim of governmental policy here is to attract "independent" foreign interests, to balance the strong position now held by large and feared corporations, such as the Standard Oil or Shell Companies. It may be assumed that a similar course will be adopted in other South American states and by the governments of former colonial areas, such as India and Indonesia.

While partnerships between private capital and governmental agencies are a war-time innovation in the United States, they have a long record of successful operation in Great Britain and in Continental Europe. ${ }^{53}$ The stock of these quasipublic corporations-such as the Anglo-Iranian Oil Co., the Czechoslovakian Grain Corporation, and the Belgian and German State Railroads-has generally been owned in one country. However, business annals contain several examples of mixed private-public corporations which combined funds and personnel originating from several countries. The pioneering role here has been played by the air transport industry. Until 1939, the originally private German corporation, Lufthansa, A.G., and the Soviet State Monopoly Aeroflot jointly owned and controlled the Dureluft

61 See H. R. Rep. No. 1527, supra note 39, at 50-52.

62 See Lawlex, The Growth of Collective Economy (1938); Munk, Legacy of Nazirsa (1943) 152-163; Phelps, The Migration of Industry to South America (1936) 166; Holmes, Brazil (Oct. 15, 1945) Foreign Policy Reports; Holmes, Argentina (Feb. 1, 1946) Foreign Policy Reports 298, 300. Recently, the Venezuelan, Colombian and Ecuadorian Governments have announced plans for joint ownership and operation of a shipping corporation. See (June 8, r946) Business WEEK II2.

${ }^{63}$ Munk, The Leghcy of Nazirsm (1943) $156-8$. 
Company. ${ }^{54}$ For nearly ten years the Chinese Government has owned 5 I per cent of stock of the Chinese National Airways Corporation, with the remaining 49 per cent held by Pan-American Airways, Inc. While flight operations have been supervised by designees of the American company, the Chinese Government has at all times controlled a majority of the Board. Somewhat similar corporations were formed in certain Latin-American countries during the war to take over systems formerly controlled by Axis nationals. ${ }^{55}$

The quasi-public enterprise has a particularly promising future in the mining and petroleum industries. The Betancourt Government in Venezuela, predicating its position upon the traditional Hispanic doctrine that subsoil deposits are national property, has declared its intention of securing one-half of the net profits from such ventures by direct participation or recapture of profits through taxation. The pattern of the future is perhaps foreshadowed by the recently announced contract between the Colombian Government and Mr. David Daniel Feldman, an independent Texas producer, for joint exploitation of oil reserves in a large area. A similar contract is reportedly being negotiated for refining of petroleum delivered to the Venezuelan Government by concessionaries. ${ }^{56}$ Areas now barred to United States petroleum firms by legislation or national policy ${ }^{5 \tau}$ may be opened if similar arrangements are made. Particularly in the Far East, American business can capitalize on a reservoir of good will if it is willing to sacrifice high short-run profits for long-run security.

Another type of business organization which may open new fields for direct foreign investment are the Corporaciones de Fomento, established since 1939 in approximately ten of the Latin-American Republics. ${ }^{\tilde{s}}$ These developmental agencies were designed to encourage expansion of industry into virgin fields and agriculture, generally with the aid of loans from the United States Export-Import Bank. The Société Haitiano-Américaine de Développement Agricole and the Corporacíon Ecuatoriana de Fomento have directorates drawn evenly from the United States and the local country, but the usual practice is one of exclusive local control.

The functions of these organizations could be increased if minority stock inter-

\footnotetext{
os Lissitzyn, International Air Transport and National Policy (1942) 400; Tomid, Inteknamonal Organization in European Air Transport (1936) $34-5$.

Announcement was made in the spring of 1946 of the organization of Linee Acree Italianc, a corporation jointy owned by the Italian Government and Transcontinental and Western Airlincs, Inc. Sce Department of State, Press Release No. 323, issued May 13, 1946; (May II, 1946) Business WeEk 5.

${ }^{5 \sigma}$ SoULE, EFRON \& NESS, op. cit. stupra note 37 , at $3 \pi_{3}$.

${ }^{58}$ See New York Times, May I4, 1946, p. 8; New York Herald Tribune, May 17, 1946, p. 6.

${ }^{57}$ For a partial list of such countrics, see 8 Jennings, Report of the Group on AMerican Petroleum Interests in Foretgn Countries (I945) I7; see also Mineral Resources, Production and Trade of Brazil (1941) 4 Foreign Mineral Qunrterly 5; Holman, American Oil Companies in Foreign Petroleum Operations, in Fanning (Ed.), OUR Oil Resources (1945) II, 50.

${ }^{58}$ See Soule, Efron \& Ness, op. cit. supra note 37 , at 273-284; U. S. Tariff Comm., The Fomento Corporstion of Latin America (1943). Many of the corporations were organized during the war to assist in production of raw materials ordinarily procured by the United States in the Far East. DeWilde, Wartime Economic Cooperation in the Americas (Feb. 15, 1942) ForeIgn Policy Reponts. However, they have equally important funetions to perform in the postwar world. For recent activity by the Chilean Corporacion de Fomento de la Produccion, see (March, 1946) Fed. Res. Burt. 230.
} 
ests were sold to local investors ${ }^{59}$-who have been traditionally reluctant to risk their funds independently, except in land speculation-and if the Export-Import Bank participated as a stockholder rather than as a creditor. The Chilean Corporacion de Fomento de la Produccíon, the oldest and best financed, has already entered into contracts with foreign interests for joint operation of new tire and chemical factories. ${ }^{60}$ It is believed that several of the other developmental corporations would be willing to embark upon such joint ventures.

Still another pattern of mixed international enterprise is the management-royalty contract, exemplified in the recent agreement between the Chinese Government and the Westinghouse Electric International Co. Under this type of arrangement the foreign corporation need not possess any stock interest or direct managerial responsibility in the local plant, its function being restricted to providing patents, working processes and technical assistance in return for fixed fees and royalty payments geared to output. ${ }^{61}$

\section{Reappraisal of Conventional Procedures for Adjusting Disputes}

In suggesting that foreign investors should primarily concern themselves with devising techniques of investment which will minimize the dangers of conflict with local authorities, we do not mean to imply that the conventional procedures for handling crisis situations do not need revision.

More precise draftsmanship of concession contracts, however wearisome a detail, would accelerate the adjustment of disputes by simplifying the terms of contention. A particularly useful innovation would be the inclusion in concession contracts of formulae for determining the indemnification for property expropriated. If such local rules of law as the Hispanic doctrine that subsoil wealth is inalienable national property $^{62}$ and that the concessionaire merely obtains an operating franchise were formally embodied in the contracts, the disappointed expectations of foreign investors would nbt become the occasion for international acrimony.

In the past, claims by foreign interests of unfair treatment have been left for settlement by ad hoc procedures. Negotiations between private interests and local governments-perhaps supplemented by diplomatic "good offices"-are obviously a desirable initial move and in recent years have frequently resulted in quick adjustments. Because of the absence of an independent judiciary in most undeveloped countries, resort to local judicial and administrative remedies-while a proper recognition of the sovereignty of the local government-is often a blind alley resulting only in delay. Except in the case of the few countries which have accepted the

\footnotetext{
${ }^{50}$ There are now substantial local private stockholdings in the Colombian Instituto do Fomento Industrial.

${ }^{\circ 0}$ See Wythe, Industry in Latin AMerica (1945) 201.

${ }^{21}$ (June I, 1946) BusinesS WeEK II3, Ir5.

12 See Barker, Mexican Mining Concessions with Special Reference to the Foreign Investor (193I) 5 So. Cal. L. Rev. I-8; Person, Mexican Orl (I942) 62-3, 73-4; but cf. Standard Oil Co. (N. J.), Present Status of the Mexican Oll Expropriations (r940) 54-60.
} 
compulsory jurisdiction clause of the International Court of Justice Charter, disputes which are not settled in this preliminary stage can be submitted to the Court or a special arbitral tribunal only with the consent of the local government and the government of the disgruntled investor.

This procedure has at least two disadvantages. In the first place, there is usually a long delay before the identity of the tribunal and the terms of the reference are agreed upon. In the meantime business operations are in a state of suspense. In the second place, a dispute which actually concerns only one government and a particular individual or organization in another country needlessly develops into an international controversy.

We believe that the most efficacious procedure for handling disputes over the fairness of indemnification provisions or of allegedly discriminatory legislation (as well as controversies occasioned by defaults on loan contracts) would be the creation of a special tribunal whose jurisdiction could be invoked by aggrieved investors without recourse to their own governments. To prevent the overcrowding of the calendar of such a tribunal with unimportant matters, it would be advantageous to devise a selective technique akin to the certiorari procedure of the United States Supreme Court.

This suggestion involves a measure of departure from the traditional conception that only states are subjects of international law and proper parties before International tribunals. However, in recent years there has been a growing and desirable tendency to depart from this doctrine and permit individuals to press their own claims against states. Thus, the statute of the former Central American Court of Justice permitted citizens of signatory states to present claims on their own behalf against the other member nations; a similar procedure was adopted by certain of the Mixed Tribunals established under the treaties of peace after the first World $\mathrm{War}^{63}$

We think it plain that this type of dispute should not be referred to the International Court of Justice. The Statute of the Court extends jurisdiction only to controversies between states; ${ }^{64}$ it is perhaps impossible, and at any rate undesirable, to obtain a general modification of this limitation. In addition, the judges of the International Court have no special competence in handling disputes which are predominantly economic in origin and which, because of the absence of controlling principles of law, will often require settlement by mediation. ${ }^{65}$ However, it would probably be desirable, in situations where the government of the unsuccessful litigant espoused his claim, to permit an appeal from the proposed tribunal to the International Court on any relevant question of international law or treaty interpretation.

The political problems of establishing the proposed tribunal raise issues beyond

${ }^{\text {ez }}$ Sec Hudson, Internatzonal Tribunals (1944) 201.

"4 Statute of the International Court of Justice, Ch. II, Article 34(x).

${ }^{o}$ Cf. Hudson, International Tribunals (1944) c. i7; League or Nations, Report op the ComMITTEE FOR THE StUdy OF INTERNATIONAL LOAN CONTRACTS (1939); Salazar, Future Foreign Investors (1941) i Proceedings of the Inter-Amgerican Bar Associatton 425, 430-I. 
the scope of this article. Obviously, its creation would necessitate either a new multilateral agreement or modification of the United Nations Charter. If other procedures are unavailable, the Board of Governors of the International Bank for Reconstruction and Development-which will probably be the largest international creditor in the next decades-could reasonably make adherence to the necessary agreement a condition prerequisite to receipt of financial assistance.

\section{Concluding Remarks}

Except in time of war, the direct foreign investor has faced few special problems in such countries as England, France, Switzerland or the United States. It is significant that the Chinese Republic-which for years denied foreigners the right to own more than 49 per cent of the stock of any company engaged in manufacturing or mining-repealed this legislation during the war after extraterritorial privileges and foreign control of tariff rates were terminated by international agreements. ${ }^{6 B}$ We conclude that the ultimate safety of foreign capital is dependent upon the rapidity with which the economies of backward areas are modernized and upon the emergence of a political system in which small nations can be confident that their rights will be fully respected in practice.

To the extent that national and international policies are directed toward the attainment of these objectives, foreign capital will benefit by the alleviation of national inferiority complexes which, even in the absence of specific grievances, breed expropriation and discrimination. The private investor cannot be expected to attain these goals on his own initiative. On the other hand, business interests have a vital interest in supporting the creation of a working International order-without which liberty and property alike will become mere artifacts to puzzle the archaeologists of the future.

\footnotetext{
'os See Rosinger, China as a Postwar Market (Jan. I, 1945) Foreign Policy Reports; Chinese News
} Service, China at War (Oct., 1943) 68-7o. 